\title{
Biotechnological potential assesment of noni fruit (Morinda citrifolialinns)
}

\begin{abstract}
Morinda citrifolia, popularly known as noni, has had its cultivation and consumption rapidly spread all over the Brazilian territory due to its phytotherapeutic properties. The biotechnological and pharmacological potential of noni were investigated herein. Testing was performed to determine hemagglutinating, antitriptic and cheliprotic activity and the phenolic compounds present in both pulp and seed. Raw noni pulp and seeds extracts from three different buffers were tested. Noni samples presented protease inhibitors, low phenolic compound content and hemagglutination of papain and trypsin treated type A blood. The inhibitory activities found in noni fruit (both for trypsin and chymotrypsin) point towards a great potential for the purification of bioactive molecules. Lectins manifest a number of exploitable biological activities, such as antiproliferative, antitumor, and immunomodulatory. Thus, it is stated that exotic fruit extracts are of interest to the food industry due to their biotechnological and pharmaceutical potential
\end{abstract}

Keywords: morinda citrifolia, benefits of noni, bioactive compounds
Volume 5 Issue 4 - 2017

\author{
Anielle Machado da Silva Lima,' Raphaella \\ Mayane Soares de Araújo,' Juliany Caroline \\ Silva de Sousa', Amanda Fernandes de \\ Medeiros, ${ }^{2}$ Raphael Paschoal Serquiz, ${ }^{3}$ \\ Alexandre Coelho Serquiz ${ }^{4}$ \\ 'Nutritionist, Federal University of Rio Grande do Norte, Brazil \\ ${ }^{2}$ Doctoral candidate in Biochemistry, Federal University of Rio \\ Grande do Norte, Brazil \\ ${ }^{3}$ Master in Biochemistry, Federal University of Rio Grande do \\ Norte, Brazil \\ ${ }^{4}$ Doctor in Health Sciences, Federal University of Rio Grande \\ do Norte, Brazil
}

\section{Correspondence: Alexandre Coelho Serquiz, Doctor in Health Sciences by Program in Health Sciences, Federal University of Rio Grande do Norte-UFRN, Brazil, Email alexandreserquiz@gmail.com}

Received: November 18, 2017 | Published: December 19, 2017
Abbreviations: LQFPB, laboratory of chemistry and bioactive proteins function; BApNA, benzoyl-DL-arginine-p-nitroanilide; con A, concanavalin A

\section{Introduction}

The diet-health binomial represents a new paradigm in the study of food. ${ }^{1-3}$ In this scenario, the discussion on adequate food providing not only energy and essential nutrients, but also non-nutrient constituents arises. When gathering these constituents, beneficial physiological effects are identified, such as the prevention or retardation of conditions, as cardiovascular disease, cancer, intestinal infections, and obesity, among others., ${ }^{2,3}$ Thus, foods with beneficial properties are called functional, nutraceuticals, planned foods, and other related synonyms. ${ }^{2}$

In this perspective, the exotic fruit market has been gaining more and more space in Brazil, due to both the alternative search by producers and the search for new fruit options by consumers. ${ }^{4} \mathrm{~A}$ fruit which stands out in science is the one from the plant Morinda citrifolia, which is a vegetable belonging to the Rubiaceae family; this fruit is commonly known as noni. Originally from southwest Asia, its cultivation and consumption have expanded rapidly in all Brazilian regions, not only because it is a rich source of nutrients, but mainly because of its herbal properties, gaining prominence in alternative medicine due to its practical use in the traditional medicine of Hawaii and Polynesia. ${ }^{5-7}$

Phytotherapic properties are attributed to several factors. Among them are the inhibitors of proteases, lectins and phenolic compounds. Protease inhibitors are present in nature from multiple sources in the animal and plant kingdoms and in microorganisms. ${ }^{8}$ These are, naturally, protective agents of plants against predator attacks. ${ }^{9}$ Lectins manifest a number of exploitable biological activities, such as antiproliferative, antitumor, and immunomodulatory. ${ }^{10}$ Phenolic compounds, in their turn, are primarily mentioned as antioxidants, not only for their ability to donate hydrogen or electrons, but also because of their stable intermediate radicals, which prevent the oxidation of various ingredients in the food, particularly fatty acids and oils. ${ }^{11,12}$

Due to these several factors, noni has been deemed as a health agent, being beneficial against cancer, infection, arthritis, hypertension, asthma, diabetes, and as an analgesic. Nevertheless, there are still few studies to evidence these properties, since it is known that several studies are necessary to safely ascertain these functional and nutritional properties. ${ }^{13}$ Therefore, this paper aims to investigate the biotechnological potential of noni in the determination of phenolic compounds in the fruit as well as its hemagglutinating and protease inhibiting activities.

\section{Materials and methods}

\section{Material}

The noni samples were commercially obtained in the city of Natal$\mathrm{RN}$ and were selected according to their quality attributes: peel color, uniformity maturation stage and defect-free. The seed and pulp were manually collected and separately stored in falcon tubes at $-20^{\circ} \mathrm{C}$ awaiting commencement of the experiments. The reagents, enzymes and equipment used during the experiments were obtained and used in the Laboratory of Chemistry and Bioactive Proteins Function (LQFPB), Department of Biochemistry, Federal University of Rio Grande do Norte. 
The equipment used was: Magnetic Stirrer-Multistirrer Magnetic Stirrer; Pipe Stirrer-Phoenix-AP 56; Bath Maria TecnalTE-056; Electronic balance-Tecnal-(mod. B-tec 2200); CentrifugeEppendorf-5804 R; Concentrator-Eppendorf-5301; Amersham Biosciences Spectrophotometer-Ultrospec 2100 pro; Blender-Bluesky; Tecnal Mill-631/2. The reagents used in the experiments were: Acetic acid (Vetec, Brazil); Hydrochloric Acid (Dynamics, Brazil); Gallic acid (Vetec, Brazil); BAPNA (benzoyl arginine nitroanilideSigma, USA); BSA (Bovine Serum Albumin-Sigma, USA); Sodium bicarbonate $\left(\mathrm{NaHCO}_{3}\right)$ (Vetec, Brazil); Bradford (Sigma, USA); Bovine trypsin enzyme (Sigma, USA); Folin Ciocalteau (Sigma, USA); Trizma Base (Sigma, USA).

\section{Preparation of the raw seed and pulp extract}

The noni seeds were dried in a ventilated oven at $60^{\circ} \mathrm{C}$ and then crushed in an industrial mill, cooled at $4^{\circ} \mathrm{C}$. The seed powder and the noni pulp were extracted in three extraction buffers: Sodium acetate, $\mathrm{pH} 4.3 ; 0.05 \mathrm{M}$ Tris-HCl, $\mathrm{pH} 7.5$ and Tris-Glycine $\mathrm{pH}$ 11.5, at the ratio of $1: 10(\mathrm{w}: \mathrm{v})$, for 3 hours of constant stirring at $24^{\circ} \mathrm{C}$. After stirring, the samples were centrifuged at $4^{\circ} \mathrm{C}$ for 30 minutes with a rotation of $8000 \mathrm{xg}$. The supernatant obtained was then filtered, the sediment was discarded and the supernatant, thus named raw extract, stored in falcon tubes.

\section{Soluble proteins dosage}

Protein dosage was performed as determined by Bradford method, ${ }^{14}$ for the raw extract obtained in each of the extraction buffers used for the noni seeds and pulp. Absorbance readings were performed at $595 \mathrm{~nm}$.

\section{Inhibitory activity detection for trypsin and quimotrypsin}

Protease inhibitory activity was tested for trypsin and chymotrypsin. The inhibitory activity tests for trypsin in the noni samples were carried out as described by Kakade et al. ${ }^{15}$ The bovine pancreatic trypsin enzyme at the concentration of $0.3 \mathrm{mg} / \mathrm{ml}$ was used in the tests and BApNA (benzoyl-DL-arginine-p-nitroanilide) was used as the substrate for the reaction. The reading was performed in a spectrophotometer at $410 \mathrm{~nm}$. Control tests were performed and the tests were done in triplicate. The results were expressed in IU (inhibition unit)/mg of the sample dry weight. The inhibition unit represents the difference between the enzymatic activity of the enzyme (control) and the tests (samples), being $1 \mathrm{IU}$ equal to $0.01 \mathrm{~nm}$.

The inhibitory activity experiment for chymotrypsin was conducted as described by Erlanger et al. ${ }^{16}$ The enzyme used in the test was bovine chymotrypsin at a concentration of $0.1 \mathrm{mg} / \mathrm{ml}$ containing $20 \mathrm{mM} \mathrm{CaCl}_{2}$ and azocasein at $1 \%$ as substrate. The reaction was halted with the addition of $20 \%$ trichloroacetic then centrifuged at $10,000 \mathrm{xg}$ for 10 minutes. Thus, the supernatant from each sample was alkalized with $\mathrm{NaOH}_{2} \mathrm{~N}$ at the ratio 1:1. The absorbance was measured in a spectrophotometer at $440 \mathrm{~nm}$. Control tests were performed and the tests were done in triplicate.

\section{Polyacrylamide gel electrophoresis}

Polyacrylamide gel electrophoresis with $10 \%$ SDS was performed as to Laemmli. ${ }^{17}$ Glass plates $(10 \mathrm{x} 14 \mathrm{~cm}), 0.75 \mathrm{~mm}$ spacers and 30:2 acrylamide/bisacrylamide stock solution were used. The $15 \%$ concentration separation gel was prepared, containing: $0.372 \mathrm{ml}$ of distilled water, $1.25 \mathrm{ml}$ of $1.5 \mathrm{M}$ Tris $\mathrm{HCl}$ buffer, $\mathrm{pH} 8.8,50 \mu \mathrm{l}$ of $10 \% \mathrm{SDS}, 3.0 \mathrm{ml}$ of acrylamide/bisacrylamide stock solution, $25 \mu \mathrm{l}$ ammonium persulfate and $3.0 \mathrm{ul}$ concentrated TEMED. The concentration gel was prepared at the concentration of $3.5 \%$ with $1.5 \mathrm{ml}$ of distilled water, $0.625 \mathrm{ml}$ of $1.5 \mathrm{M}$ Tris- $\mathrm{HCl}$ buffer, $\mathrm{pH} 8.8$, $25 \mu 1$ of $10 \% \mathrm{sds}, 0.33 \mathrm{ml}$ of acrylamide/bisacrylamide stock solution, $12.5 \mu \mathrm{l}$ of ammonium persulfate and $2.5 \mu \mathrm{l}$ of TEMED concentrate.

In the gel, $9 \mu \mathrm{g}$ of protein from each sample, solubilized in a sample buffer composed of $0.0625 \mathrm{M}$ tris- $\mathrm{HCl}, 2 \%$ SDS, $10 \% \mathrm{v} / \mathrm{v}$ glycerol, and $0.01 \%$ bromophenol blue in a volume of $20 \mu 1$ were applied to the gel. The running buffer consisted of $0.025 \mathrm{M}$ base Trism, $0.192 \mathrm{M}$ glycine and $10 \%$ SDS. The gel was subjected to a constant electrical current of $40 \mathrm{~mA}$ for approximately 1 hour.

After running, the gels were submerged in a fixative solution composed of $25 \mathrm{ml}$ of distilled water, $5 \mathrm{ml}$ of $10 \%$ acetic acid, and $30 \mathrm{ml}$ of $30 \%$ ethanol. After a period of 30 minutes, the gels were removed from the fixative solution and stained per the procedure described by Weber et al. ${ }^{18}$ The dye solution was prepared using Comassie Blue R-250 at 1\%, 40\% methanol, and 10\% acetic acid in water. The fading was performed with a solution containing $10 \%$ acetic acid and $40 \%$ methanol.

\section{Hemaglutinant activity in globulinic fractions}

The globulin hemagglutinating activity was monitored following a methodology adapted by Pusztai et al. ${ }^{19}$ Thus, the substrate was prepared by weighing $1 \mathrm{~g}$ of hemoglobin and adding $50 \mathrm{ml}$ of $0.06 \mathrm{M}$ $\mathrm{HCl}$ under constant stirring. After the solubilization $30 \mathrm{ml}$ of $0.2 \mathrm{M}$ acetate buffer, $\mathrm{pH} 3.5$ was added and the $\mathrm{pH}$ adjusted to 3.5 , being the volume completed to $10 \mathrm{ml}$. This substrate was stored at $5^{\circ} \mathrm{C}$ waiting for further use in the tests. Aliquots of $2 \mathrm{ml}$ human types A, B and $\mathrm{O}$ erythrocytes were washed with $8 \mathrm{ml}$ of saline solution and centrifuged at $1650 \mathrm{xg}$ for 5 minutes until a mass of erythrocytes free from serum and hemolyzed material was obtained. The hematocrit was performed, and solutions of $4 \%$ erythrocytes in saline solution were prepared. Haemaglutination tests were performed by serial dilution on "V" bottom ELISA plates. $25 \mu \mathrm{l}$ of saline, $25 \mu \mathrm{l}$ of globulin $(2 \mathrm{mg} / \mathrm{mL})$, and $25 \mu \mathrm{l}$ of a $4 \%$ erythrocyte suspension were added to each container. The reaction was incubated at $37^{\circ} \mathrm{C}$ for 1 hour. The concanavalin $\mathrm{A}$ (conA) test was used as a positive hemagglutination control.

\section{Total phenolic compounds assessment}

Total phenolic compounds were measured following the Swain et al. ${ }^{20}$ A curve containing 200, 100, 50, 20, 10, $1 \mu \mathrm{g} . \mathrm{mL}^{-1}$ gallic acid $(10 \mathrm{mg} / \mathrm{ml})$ was performed as standard. Therefore, firstly, $200 \mu \mathrm{l}$ of the sample (pulp and seed) were added to the test tubes. Then, $400 \mu \mathrm{l}$ of ultrapure water and $100 \mu \mathrm{l}$ of Folin's reagent (solution of complex polymer ions formed from hybrids of phosphomolybdic and phosphotungstic heteropolyacids, which oxidizes the phenolates, reducing the acids to a blue Mo-W complex). Stirring was then performed, and the result was allowed to rest for 10 minutes at a room temperature of $24^{\circ} \mathrm{C}$. $50 \mu \mathrm{l}$ of $20 \% \mathrm{NaHCO}_{3 \mathrm{a}}$ was then added, stirred once more and placed in a water bath at $40^{\circ} \mathrm{C}$ for $20^{\prime}$. The test was conducted in triplicate and control. The absorbance readings were made using a $765 \mathrm{~nm}$ spectrophotometer. The results were expressed as mg of gallic acid equivalents/g of the sample dry weight. 


\section{Results}

\section{Soluble proteins dosage}

The best results for protein extraction were obtained in a TrisGlycine buffer. The total soluble proteins dosage of each sample are presented in Figure 1. There was a higher protein dosage in the noni seeds for the Tris-Glycine (2.66 \pm 0.48$)$ extraction than for the Acetate $(0.35 \pm 0.08)$ and Tris- $\mathrm{HCl}(0.41 \pm 0.12)$ extraction.

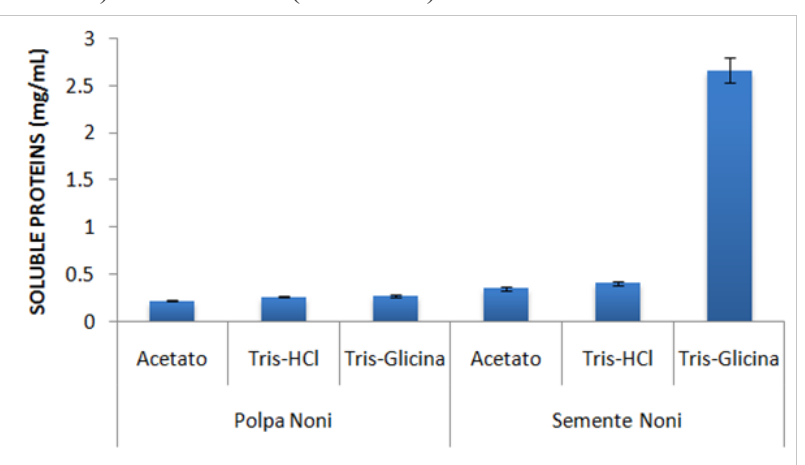

Fígure I Dosage of total soluble proteins in the raw noni pulp and seed extracts for different extraction buffers. The data is presented as mean and error bar for the experiments.

\section{Detection of inhibitory activity for trypsin and quimotrypsin}

For the noni samples the inhibitory activity results laid bare that both the fruit seed and pulp have antitryptic activity. However, among the extracts, the pulp presented the highest trypsin inhibitory activity for Tris-Glycine $(51 \% \pm 6.01)$, whereas the seed samples showed activity for nearly all Tris- $\mathrm{HCl}$ and Tris -Glycine $(41.3 \% \pm 4.34)$ and $(49.5 \% \pm 5.64)$ extractions (Figure 2$)$.

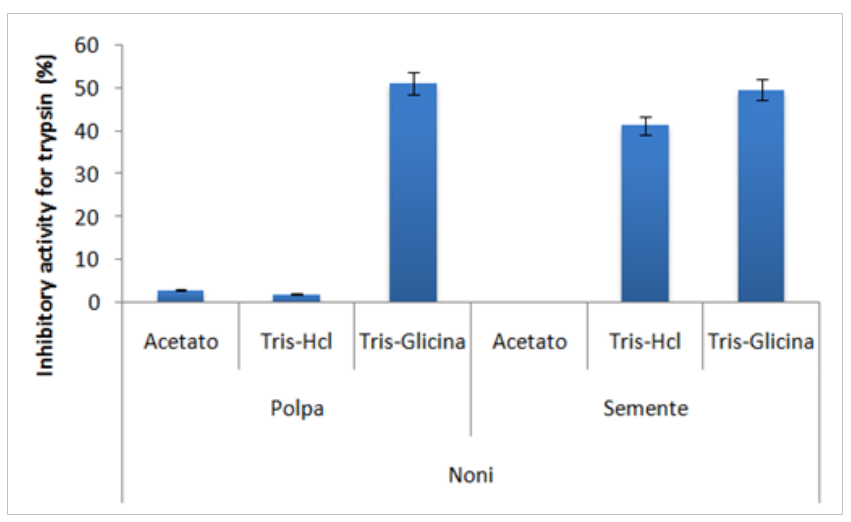

Figure $\mathbf{2}$ Inhibitory activity for trypsin for the raw noni pulp and seed extracts in different extraction buffers. The data is presented as mean and error bar for the experiments.

The results of the inhibitory activities for chymotrypsin from both samples showed that the seed samples present higher activity when compared to the pulp samples. However, among the seed extracts, the highest activity was obtained in for Tris-Glycine $(40 \% \pm 5.21)$, followed by the extraction in Tris-Hcl $(29 \% \pm 3.46)$, as may be as seen in figure 03. In the pulp extracts no activity that may evidence the possibility of inhibitors of chymotrypsin was obtained (Figure 3).

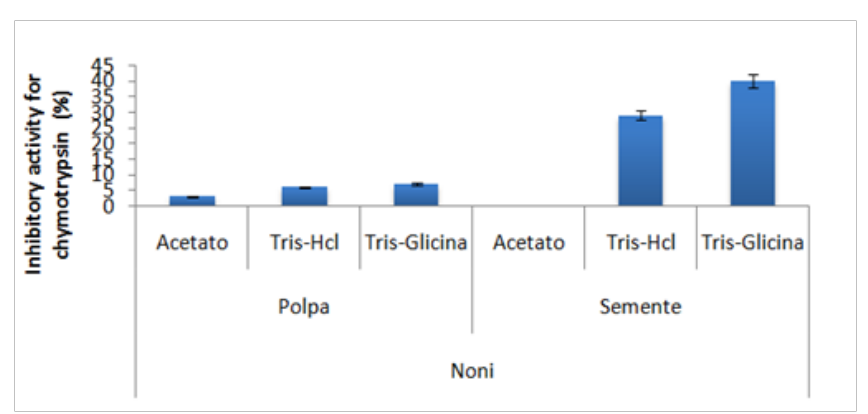

Figure 3 Inhibitory activity for chymotrypsin for the raw noni pulp and seed extracts in different extraction buffers. The data is presented as mean and error bar for the experiments.

\section{Electrophoresis in polyacrylamide gel}

In the electrophoresis gel the proteins from the pulp (Figure 4A) and seed (Figure 4B) extracts can be visualized for the different extraction types: Sodium acetate, $\mathrm{pH} 4.3$ (A); $0.05 \mathrm{mM}$ Tris-HCl, $\mathrm{pH}$ $7.5(\mathrm{~T})$ and Tris-Glycine $\mathrm{pH} 11.5(\mathrm{G})$. In the noni pulp gel, proteins with a very light coloration between the molecular masses 7 to $48 \mathrm{kDa}$ are visualized, whereas in the seed samples a more intense coloration is observed in the range of molecular mass from 7 to $48 \mathrm{kDa}$. The seed sample extracted with Tris-Glycine shows that further to the presence of bands in the range from 7 to $48 \mathrm{kDa}$, it also presents heavier proteins with molecular weight of approximately $100 \mathrm{kDa}$.

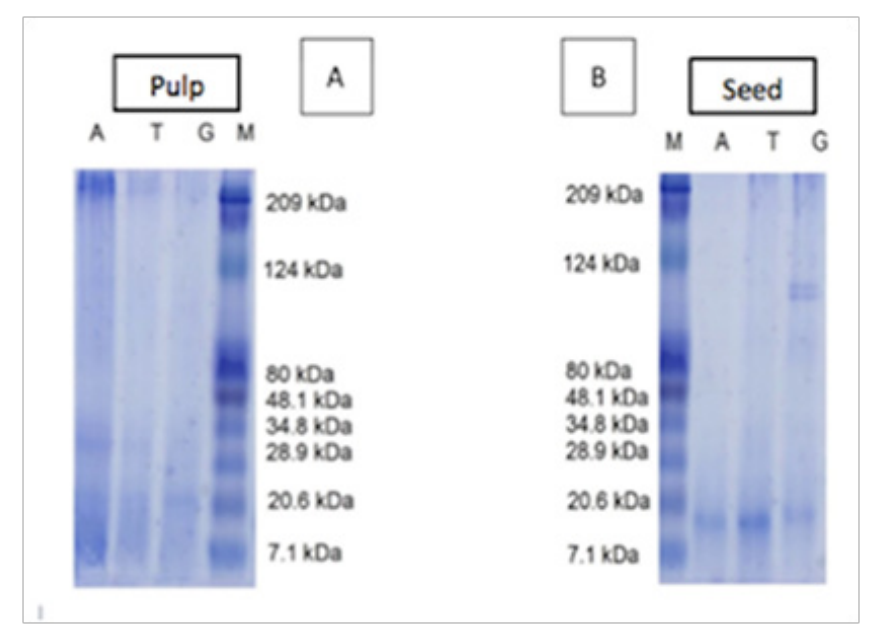

Figure 4 Polyacrylamide gel electrophoresis in the noni pulp (A) and seed (B) samples. Sodium acetate, $\mathrm{pH}$ 4.3: A. $0.05 \mathrm{mM}$ Tris- $\mathrm{HCl}$, $\mathrm{pH}$ 7.5: T; and TrisGlycine $\mathrm{pH}$ I I.5: G.

\section{Hemaglutinant activity in globulinic fractions}

The seed extracts presented titers higher than 1024units of haemagglutination for the samples extracted with Tris-Glycine for Type A blood treated with papain and trypsin.

\section{Evaluation of total phenolic compounds}

The phenolic compounds Table 1 of the noni pulp and seed samples demonstrated that the seed has the highest amount of phenolic compounds: acetate $(0.43 \pm 0.01)$, Tris-HCL $(0.20 \pm 0.03)$, and Tris-Glycine $(0.27 \pm 0.07)$. 
Table I Phenolic compound content of noni pulp and seed. The results are expressed as milligrams equivalent of gallic acid/gram of sample. The data are presented as mean \pm standard deviation for the experiments

\begin{tabular}{llll}
\hline Sample & & Mean $(\mathbf{m g} / \mathbf{g}$ Gallic acid equivalents) & Standard deviation \\
\hline \multirow{2}{*}{ Noni Seed } & Acetate & 0,43 & 0,01 \\
& Tris_HCl & 0,20 & 0,03 \\
& Tris-Glicina & 0,27 & 0,07 \\
& Acetate & 0,19 & 0,04 \\
\multirow{2}{*}{ Noni Pulp } & Tris_HCl & 0,18 & 0,06 \\
& Tris-Glycine & 0,11 & 0,08
\end{tabular}

\section{Discussion}

Fruit, in general, are not a source of protein and tend to present low values for these macronutrients. ${ }^{21}$ Components which can normally raise the amount of proteins in the fruit are the seeds, ${ }^{22}$ which are protein-rich components. ${ }^{23}$ In the paper herein it was observed that the noni seed extracts stand out because they contain larger amounts of proteins, which enables to suppose that these extracts contain larger amounts of protein inhibitors.

The considerable values of soluble proteins in the samples laid bare a high possibility of finding protease inhibitors. A prominent sample in this context was the seed extracted with Tris-Glycine (2.66 \pm 0.48$)$. This evaluation of the protein content showed a great tendency for the presence of active peptides, given the fact that in all samples protein content was evidenced. Despite the fact that fruits are not a source of proteins, other works have identified the presence of peptidiosbioativos in several fruits, from which we can highlight soursop and pineapple. ${ }^{24,25}$

An inhibitory activity for trypsin between 40 and $50 \%$ was found in seeds; for chymotrypsin, results were found between 29 and $40 \%$; other studies show the presence of trypsin and chymotrypsin inhibitors in fruits, but the noni fruit obtained higher results when compared to these other fruits. ${ }^{26}$ The result of the electrophoresis gel test for the seed samples helped to support the thesis that this activity is actually from protein, because it contains molecular weight bands normally visualized in these families of inhibitors ( 7 to $40 \mathrm{kDa}){ }^{26}$

Protease inhibitors have been the subject of several studies, mainly due to their positive effects in experimental models, which are highlighted in studies conducted by Serquiz (2012), which showed satiety in rats supplemented with trypsin inhibitors, further to anti-inflammatory and anticancer actions in rats supplemented with chymotrypsin inhibitors, as well as its use in anti-AIDS drug. ${ }^{7}$

The haemagglutination results showed titers higher than 1024units of haemagglutination for the seed samples extracted with Tris-Glycine for Type A blood, thus being a great potential for the isolation of these substances. Lectins, in their turn, manifest a number of exploitable biological activities, such as antiproliferative, antitumor, and immunomodulatory. ${ }^{10}$ This characterizes this molecule as a potential beneficial action mechanism in various morbidities, such as cancer.

Studies with total phenolic compounds showed that pulp extracts with acetate $(0.19 \pm 0.03)$, Tris-HCL $(0.18 \pm 0.03)$, and Tris-Glycine $(0.11 \pm 0.1,06)$ presented lower values than the seed extracted with acetate $(0.43 \pm 0.01)$, Tris-HCL $(0.20 \pm 0.03)$, and Tris-Glycine $(0.27 \pm 0.07)$. Studies with other fruits showed a higher content of phenolic compounds, such as studies which identified this in fruits like acerola $(14.89 \pm 1.01)$, cashew $(2.48 \pm 0.15)$, strawberry $(2,41 \pm 0,02)$ and guava $(1,24 \pm 0,04) .{ }^{27}$ It is important to note that no studies were found on phenolic compounds in the noni seed. This is a possibility for ingestion of the seed, which is often lost and not reused.

The food industry has been showing great interest in extracts of plants rich in phenolic compounds, since these compounds delay the degradation of several nutrients found in industrialized foods, thus increasing the quality and nutritional value of these foods. ${ }^{28}$

Some authors have found positive correlations between the total amount of phenolic compounds and the antioxidant activity of fruits $^{29}$ and antioxidants are compounds that can prevent chemical and biological free radicals from causing oxidative damage to the organism, ${ }^{30}$ thus bringing great benefits to individuals as well as to the State through a reduction of public health costs.

The ADA, ${ }^{31}$ states that fruits are one of the simplest forms of functional foods. In a study on feeding, nutrition and prevention of chronic noncommunicable diseases ${ }^{32}$ this becomes clearer by the finding of new molecules contained in these foods, ${ }^{33}$ which increasingly present beneficial activities in humans.

In the experiments three types of buffers at different $\mathrm{pH}$ (sodium acetate, $\mathrm{pH} 4.3,0.05 \mathrm{mM}$ Tris- $\mathrm{HCl}, \mathrm{pH} 7.5$ and Tris-Glycine $\mathrm{pH} 11.5$ ) were used and the buffers used in the experiments were such that the $\mathrm{pH}$ of the medium remained constant. These different $\mathrm{pHs}$ influenced the protein solubility of the samples. ${ }^{34}$

\section{Conclusion}

The noni seeds extracted in Tris-Glycine presented a greater amount of total soluble proteins, which may comprise bioactive peptides. The tryptic and chymotryptic activity were presented in the seed samples extracted in Tris-glycine and Tris-HCL and the pulp showed antitriptic activity for the Tri-sglycine extract. The phenolic compounds were determined and the quantity is higher in the seeds. Hemagglutinating activity pointed towards the presence of a probable lectin, a potential substance used in many studies. Therefore, the presence of proteins with potential bioactivity and phenolic compounds was verified.

\section{Acknowledgements}

None.

\section{Conflicts of Interest}

None. 


\section{References}

1. Kucuk O. New opportunities in chemoprevention. Cancer Invest. 2002;20(2):237-245.

2. Bidlack WR, Wang W. Planejamento de alimentos funcionais. In: Shils ME, et al. editors. Tratado de nutrição moderna na saúde e na doença. 9th ed. Rio de Janeiro: Manole, Brazil; 1999. p. 1959-1970.

3. Borges VC. Alimentos funcionais: prebióticos, probióticos,fitoquímicos e simbióticos. In: Waitzberg DL. Nutrição oral,enteral e parenteral na prática clínica. 3rd ed. São Paulo, Brazil; 2000. p. 1495-1509.

4. Renata aparecida de andradei, eliana gertrudes de macedo lemosii, antonio baldo geraldo martinsIII, Rinaldo César de PaulaIV, José Luiz Pitta. Caracterização morfológica e química de frutos de rambutan. Rev Bras Frutic. 2008;30(4):958-963.

5. Assi RA. Morinda citrifolia (Noni): A comprehensive review on its industrial uses, pharmacological activities, and clinical trials. Arabian Journal of Chemistry. 2017;10(5):691-707.

6. Nascimento, Liane Caroline Sousa. Caracterização Centesimal, Composição Química e Atividade Antioxidante do Noni (Morinda Citrifolia L.) Cultivado no Município de Zé Doca-MA. 69p Dissertação (Mestrado em Ciência e Tecnologia de Alimentos). Instituto de Tecnologia, Departamento de Tecnologia de Alimentos, Universidade federal rural do Rio de Janeiro, Seropédica, RJ, Brazil

7. Wang MY, West BJ, Jensen CJ, et al. Morindacitrifolia (noni): A literature review and recent advances in noni research. Acta Pharmacologica Sinica. 2002;23(12):1127-1141.

8. Laskowski M JR, Kato I. Protein Inhibitors. Annual Review of Biochemistry. 1980;49:593-626.

9. Lajolo FM, Genovese MI. Nutritional significance of lectins and enzyme inhibitors from legumes. Journal of Agricultural and Food Chemistry. 2002;50(22):6592-6598

10. Yingying Wu, Hexiang Wang, Tzi Bun Ng. Purification and characterization of a lectin with antiproliferative activity toward cancer cells from the dried fruit bodies of Lactarius flavidulus. Carbohydr Res. 2011;346(16):2576-2581.

11. Cuvelier ME, Richard H, Berset C. Comparison of the antioxidant activityof some acid phenols: structure-activity relationship. Bioscience Biotechnology and Biochemistry, Benkyoku. 1992;56(2):324-325.

12. Maillard MN, Soum MH, Boivia P, et al. Antioxidant activity of barley and malt: relationship with phenolic content. Lebensmittel-Wissenschaft \& Technologie. 1996;29(3):238-244.

13. Ahmad AN, Mat Daud ZA. Ismail, A. Review on potential therapeutic effect of Morinda citrifolia L. Current Opinion in Food Science. 2016;8:62-67.

14. Bradford M. A rapid and sensitive method for the quantitation of microgram quantities of protein utilizing the principle of protein-dye binding. Anal Biochem. 1976;72:248-254.

15. Kakade ML, Rackis JJ, MC Ghee JG. An evaluation of natural vs. synthetic substracts for measuring the anti tryptic activity of soy bean samples. Cereal Chemistry. 1969;46:518-526.

16. Erlanger BF, Kokowsky N, Cohen W. The preparation and properties of two new chromogenic substrates of trypsin. Arch Biochem Biophys. 1961;95:271-278
17. Laemmli UK. Cleavage of structural proteins during the assembly of the head of bacteriophage T4. Nature. 1970;227(5259):680-685.

18. Klaus Weber and Mary Osborn. The reliability of molecular weigh determinations by dodecyl sulfate-polyacrylamide gel electrophoresis. $J$ Biol Chem. 1969;244:4406-4412.

19. Pusztai A, Watt WB, Stewart JC. Erytro-and lymphoagglutinin of Phaseolusaconitifolius. Phytochemistry. 1987;26:1009-1013.

20. Swain T, Hills WG. The phenolic constituents of prunusdomestica. Journal of the Science of Food and Agriculture. 1959;10:63-69.

21. Sousa Mariana Séfora Bezerra, VIEIRA, Luanne Morais, et al. Caracterização nutricional e compostos antioxidantes em resíduos de polpas de frutas tropicais. Ciênc agrotec. 2011;35(3):554-559.

22. Jussara A Melo Gondim, Maria de Fátima V Moura, et al. Composição centesimal e de minerais em cascas de frutas. Ciência e Tecnologia de Alimentos. 2015;25(4):825-827.

23. Roberta Roesler, Luciana Gomes Malta, Luciana Cristina Carrasco, et al. Atividade antioxidante de frutas do cerrado. Ciênc Tecnol Aliment. 2007;27(1):53-60.

24. Baskar R, Rajeswari V, Kumar TS. In vitro antioxidant studies in leaves of Annona species. Indian Journal of Experimental Biology. 2007;45(5):480-485.

25. Brandão WAPLNTM, Seibert, Diviane, Mendonça SNTG de, et al. Bebida fermentada probióticade soro de leite. Higiene Alimentar. 2006;20(143):56-59.

26. Sgarbieri VC. Substâncias tóxicas e antinutricionais de ocorrência natural em alimentos. Faculdade de Engenharia de alimentos-UNICAMP. Campinas Brasil; 1986.

27. Juliana Mesquita Freire, Celeste Maria Patto de Abreu, Denise Alvarenga Rocha, et al. Quantificação de compostos fenólicos e ácido ascórbico em frutos e polpas congeladas de acerola, caju, goiaba e morango. Cienc Rural. 2013;43(12):2013.

28. Pan Y, He C, Wang H, et al. Antioxidant activity of microwave-assisted extract of Buddleia officinalis and its major active component. Food Chemistry. 2010;121(2):497-502.

29. Mosmann T. Rapid colorimetric assay for cellular growth and survival: application to proliferation and cytotoxicity assays. J Immunol Methods. 1983;65(1-2):55-63.

30. Barreiros, André LBS, David, et al. Estresse oxidativo: relação entre geração de espécies reativas e defesa do organismo. Quím Nova. 2006;29(1):113-123.

31. American dietetic association. Position of the American Dietetic Association: functional foods. J Am Diet Assoc. 1999;99(10):1278-1285

32. World Health Organization. Food and agriculture organization. Diet, nutrition and the prevention of chronic diseases. Geneva WHO-Technical Report Series; 2003. p. 1-160.

33. Yang J. Total phenolics, ascorbic acid, and antioxidant capacity of noni (Morindacitrifolia L.) juice and power as affected by illumination during storage. Food Chemistry. 2010.

34. Sgarbieri VC. Propriedades funcionais de proteínas em alimentos. Boletim da Soc Bras Ciência eTecnologia de Alimentos. 1998;32(1):105-126. 